\title{
Improving the Performance of Small Micro Enterprises Through the Implementation of Digital Marketing
}

\author{
Abdul Hakim Arifin Mahmudin A. Sabilalo \\ STIE Enam Enam Kendari, Indonesia
}

\begin{abstract}
The growth of micro and small businesses in Kendari City cannot be separated from the role of business actors who take advantage of the current development of internet technology. The Southeast Sulawesi MSME Forum conducted an initial survey in 2020 covering 45 MSEs, consisting of 42 micro businesses and 3 small businesses and showed that the number of respondents who use the internet to promote and sell their products such as facebook, instagram, whatsapp and youtube websites reached $72 \%$. and $28 \%$ of them have not used the internet media.

MSMEs can take advantage of digital marketing, but empirically there are still many who have not made maximum use of it due to limited knowledge of the media used. The level of utilization of digital marketing is quite high but sales turnover made through online media is 16 MSEs only able to sell their products below $10 \%$ of turnover, 20 MSEs with turnover below 50\% and the remaining 9 MSEs with a turnover of 50\% and above. Therefore, it is very important to examine the role of digital marketing in improving the performance of micro and small businesses.

The purpose of this research is to improve the performance of micro and small businesses. The stages of the research method are (a) Develop instruments as well as test validity and reliability, (b) The data that has been obtained are then tabulated according to the observed variables. Furthermore, it is described, (c) conducting analysis and discussion related to the role of digital marketing in improving the performance of micro and small businesses. (d) examine the appropriate model for improving the performance of micro and small enterprises. (e) Draw conclusions and provide recommendations on improving the performance of micro and small enterprises through the resulting model.

The output target is a Sinta accredited national journal. 5. The proposed level of Technology Readiness (TKT) is 2, namely Digital marketing, has been identified, theoretical/empirical studies) allow digital marketing technology to be applied; The theoretical and empirical designs have been identified; The basic elements of the digital marketing technology that will be developed are known; The characterization of the digital marketing technology components that will be used has been mastered and understood; The performance of each of the constituent elements of the technology to be developed has been predicted; Preliminary analysis shows that the main digital marketing functions needed are working well; Models and simulations to test the correctness of the basic principles of digital marketing technology have been created; Analytical research to test the correctness of the basic principles of digital marketing technology has been carried out; The components of digital marketing technology that will be developed separately can work well; The equipment used has been tested for validity and reliability and the stages of using digital marketing are known.

The results of the study found that improving the performance of micro and small businesses can be done by implementing digital marketing, namely implementing an increase in business perspective, increasing distribution, increasing goods and services using customer feedback, awareness of business image, building interaction with customers and increasing the number of consumers. To make the application of digital marketing effective, Micro and Small Business actors need to increase their knowledge of digital marketing, increase the level of internet use and use various types of social media.
\end{abstract}

Keywords: Digital Marketing, UKM Performance

DOI: $10.7176 / \mathrm{EJBM} / 13-20-09$

Publication date:October $31^{\text {st }} 2021$

\section{PRELIMINARY}

Internet marketing is intended to achieve marketing objectives through the application of digital technology (Dave Chaffey (2006). Consumption over the last 10 years of digital media proves the internet to be important for all categories. Therefore, the internet as a communication medium has expanded the scope of marketing communications. richness of marketing communications by combining text, video, and audio content into compelling messages. Thus, the web is arguably richer as a medium than some traditional media (Laudon and Traver, 2013).Furthermore, the Internet has succeeded in expanding the intensity of market information by providing marketers and customers with real-time information as they transact in the marketplace.

Consumers are much more available to receive marketing messages because of the always-on environment created by mobile devices which results in a tremendous increase in marketing opportunities for companies (Laudon and Traver 201). The digital era is unavoidable. Marketing expert Yuswohadi revealed that if you want to survive, SMEs must be able to maximize the benefits of digital marketing (Maulana, 2018). Digital marketing 
is more prospective because it allows potential customers to obtain all kinds of information about products and transact via the internet (Dedi Purwana, 2017)

Based on data reported by We are Social, that as of 2020, there are 175.4 million internet users in Indonesia. This means that $64 \%$ of the Indonesian population has had access to the world. Percentage of internet users based on the device used, namely mobile phones (96\%), smartphones $(94 \%)$, non-smartphone mobile phones $(21 \%)$, laptops or desktop computers $(66 \%)$, tables $(23 \%)$, game consoles $(16 \%)$, to virtual reality devices $(5.1 \%)$. This implies that the potential for online shopping has been sufficiently developed in Indonesia which must be balanced with digital marketing by business actors.

Data from We are Social shows that the most widely used social media platforms in Indonesia as of January 2020 are Youtube (88\%), Whatsapp (83\%) and Facebook (81\%). The next position is occupied by Instagram ( $80 \%)$, line $(58 \%)$, Twitter $(52 \%)$. The rest are placed sequentially by FB, messenger, Line, Linkedin, BBM, Pinterest, and Wechat. (https://websindo.com/indonesia-digital-2019-media-social). According to Hiebing and Scott (2003) with the pattern of using the internet as a target, entrepreneurs need to identify the online activities of the target market.

The growth of micro and small businesses in Kendari City cannot be separated from the role of business actors who take advantage of the current development of internet technology. The Kendari City SME Forum conducted an initial survey in 2020 covering 45 SMEs, consisting of 42 micro businesses and 3 small businesses and showed that the number of respondents who use the internet to promote and sell their products such as facebook, instagram, whatsappp website and youtube reached $72 \%$ and $28 \%$ of them have not used the internet media.

Ramadhani and Yaenal (2013) in their research that SMEs can take advantage of digital marketing, but empirically there are still many who have not made maximum use of it due to limited knowledge of the media used. The level of utilization of digital marketing is quite high but the sales turnover made through online media is 16 SMEs only able to sell their products below $10 \%$ of turnover, 20 MSEs have a turnover below $50 \%$ and the rest are 9 SMEs with a turnover of 50\% and above. Therefore, it is very important. to examine the role of digital marketing in improving the performance of micro and small businesses.

\section{LITERATURE REVIEW}

Lorraine Wahu Kithinji (2014), found that the use of internet marketing has a positive impact on business performance. Mohd Irwan (2014) lack of understanding of technology will have a negative impact on small businesses. Icha (2016) effective social media marketing is even new to the marketing world and more effective when compared to traditional forms of marketing. Rini Setiowati (2015), found that a valuable insight that can educate SME managers about the potential benefits they will get is internet adoption. Ridwan (2019) found that Digital Marketing was able to create increased marketing in SMEs.

Jenyo Gabriel and Soyoye Kolapo (2015) found that today's businesses are spending more and taking part in online marketing than ever before. Mayank Kumar (2018) found that digital channels influence customer opinions because of the ease of communication between customers. Arifuddin (2019) found Digital Marketing to have a positive and significant influence on Purchase Decisions. Ugonna (2017) found that appropriate marketing communication channels have a significant influence on the regularity of visits. Furthermore, Tiffany (2018) finds that digital channels in the near future influence customer buying opinions. Then Samsona's (2014) research found that online digital media has a positive influence on potential customers' purchasing decisions

Khan and Siddiqui in their journal quoted from Purwana (2017), digital marketing comes from the internet. According to Ridwan Sanjaya and Josua Tarigan (2009), digital marketing is a marketing activity including branding that uses various web-based media such as blogs, websites, e-mail, Adwords, or social networks. Dave Chaffey (2015), digital marketing or digital marketing has almost the same meaning as electronic marketing, both of which describe the management and implementation of marketing using electronic media.

The use of the internet by SMEs facilitates instant exchange of information, stimulates efficiency and helps solve problems (Carniels, 2014). The use of social media is considered to have a positive impact on a business, in particular it can reduce large marketing costs and improve good relationships with customers (Mokhtar 2016). The use of digital marketing gives hope for SMEs to develop into centers of economic power (Purwana, 2017).

The six main channels of digital media channels according to Chaffey and Smith (2015) are: a.) Search Engine Marketing (SEM), b.) Online PR, c.) Online partnerships, d.) Interactive advertising. e.) Opt-in email marketing. f.) Social media marketing. Stelzner quoted from Purwana (2017), social media has the potential to help SMEs in marketing their products. Stockdale, Ahmed, and Scheepers succeeded in identifying the business value of using social media for SMEs, as quoted by Purwana (2017), namely as follows: a) The creation of sustainable marketing channels; b) Increase in short-term revenue and long-term sales; c) Reducing advertising costs by up to 70\%; c) Reduction in overall marketing costs; d) Creation of competitive advantage; e) Ease of promotion across social media platforms; f) Increasing the popularity of brands and products; g) Introduction of the company to the public.

Setiowati (2015) the application of ICT by SMEs in Indonesia is still very slow. According to research by Demishkevich (2015), it is important to know the level of adoption of internet marketing among small businesses. 
The most common barriers are lack of knowledge about the benefits of Computer Information Technology, concerns about security and privacy, lack of skilled workers, cultural barriers, and lack of financial resources (Khatibi, 2003).

Saptadi (2014) stated, in order to improve the competitiveness of SMEs, the Indonesian government facilitates e-business training for SMEs. Pawar (2014) explains that current customers tend to use social media more, the use of websites is now a place to provide information about products to potential buyers. Kaplan and Haenlein (2010) social media is a group of internet-based applications and is built on the ideological and technological framework of the Web 2.0 platform. Ad users can create their own content that is interesting and seen by many people.

Slyvia (2013) describes five main characteristics in social media: a) Participation, Openness c.) Conversation. d) Community, social media offers a mechanism for individuals or organizations to form communities that share common interests. e) Connectedness. Zarella (2005) says the role of social media in marketing includes: a) Social media can provide identity about the products offered. b.) Serving as marketing research in an effort to find information about consumer needs. c) Social media can be used as a communication link between marketers and consumers, d) Social media brings companies closer to consumers. e) Social media is intended to build the quality of interaction (customer engagement).

According to Chaffey (2015), there are 6 (six) categories of social media: a) Social networking. b) Social knowledge. c) Social sharing d) Social news. e) Social streaming. f) Company user-generated content and community. Muttaqin (2011) Facebook Marketing is conducting marketing activities using all the facilities provided by Facebook with the aim of increasing sales and establishing closer communication with customers.

Nisrina (2015), Instagram is an application that is used to share photos and videos. According to Atmoko (2012), as an application that is in demand by many users, Instagram is a social media that has lots of opportunities for business for its users, which can be used as a marketing communication medium. According to Atmoko (2012) indicators of a social media are: a) Hashtags. b) Location (Geotag). c) Follow. d) Share. e) Likes. Love symbol, f) Comment or comments. g) Mentions.

Law No. 20 of 2008 article 1 concerning Micro, Small and Medium Enterprises, explains:

1) Micro Enterprises are productive businesses owned by individuals and/or individual business entities that meet the criteria for Micro Enterprises as regulated in this law.

2) Small Business is a productive economic business that stands alone, which is carried out by individuals or business entities that are not subsidiaries or not branches of companies that are owned, controlled, or become part either directly or indirectly of Medium Enterprises or Large Businesses that meet Small Business criteria as referred to in this law.

Micro Business Criteria as follows:

a. Have a net worth of at most Rp. 50,000,000.00 (fifty million rupiah) excluding land and buildings for business premises; or

b. Have annual sales of a maximum of Rp. 300,000,000.00 (three hundred million rupiah)Small Business Criteria as follows:

a. Have a net worth of more than Rp 50,000,000 (fifty million rupiah) up to a maximum of Rp 500,000,000 (five hundred million rupiah) excluding land and building for business; or

b. Have annual sales of more than Rp. 300,000,000.00 (three hundred million rupiah) up to a maximum of Rp. 2,500,000,000.00 (two billion five hundred million rupiah)

Annual sales results are net sales results (net) originating from the sale of business goods and services in one year (Rahmana, 2018)

\section{METHODE}

This research was carried out in the Kendari City area, Southeast Sulawesi Province with the object of SME performance in this case being a business that grows naturally, then the local Cooperatives and UMKM Service set it as the object of guidance and facilitation in accessing capital to bank financial institutions, including conducting business management coaching. The population of this research is MSMEs in Kendari City, especially in the fashion, handicraft, and culinary industries. Sampling in this study was done by purposive sampling technique as many as 114 samples who have used digital marketing. Data collection techniques using a questionnaire, dept interview and document study. The data analysis technique used was descriptive statistical analysis and Partial Least Square analysis through the help of SPSS and Smart PLS software.

\section{RESULT}

\section{a. Profile of Small and Medium Enterprises in Kendari City}

The profile of Micro and Small Business actors in this study includes individual characteristics and business characteristics. The characteristics of Micro and Small Business actors in this study are the individual characteristics of each respondent observed in terms of age, gender, education level and family dependents. Based on the results of the research, the characteristics of Micro and Small Business actors are shown in the following 
table:

Table 1. Respondents of Small and Micro Business Actors Based on Individual Characteristics

\begin{tabular}{|c|c|c|c|}
\hline \multicolumn{2}{|c|}{ Age (Years) } & $\begin{array}{c}\text { Number of Respondents } \\
\text { (Person) }\end{array}$ & $\begin{array}{c}\text { Percentage } \\
(\%)\end{array}$ \\
\hline 1. & $27 \mathrm{~s} / \mathrm{d} 30$ & 8 & 7,02 \\
\hline 2. & $31 \mathrm{~s} / \mathrm{d} 34$ & 12 & 10,53 \\
\hline 3. & $35 \mathrm{~s} / \mathrm{d} 38$ & 21 & 18,42 \\
\hline 4. & 39 s/d 42 & 39 & 34,21 \\
\hline 5. & 43 s/d 46 & 16 & 14,04 \\
\hline 6. & $47 \mathrm{~s} / \mathrm{d} 50$ & 7 & 6,14 \\
\hline 7. & $51 \mathrm{~s} / \mathrm{d} 54$ & 6 & 5,26 \\
\hline 8. & $55 \mathrm{~s} / \mathrm{d} 58$ & 5 & 4,39 \\
\hline \multicolumn{4}{|c|}{ Gender } \\
\hline 1. & Man & 51 & 44,67 \\
\hline 2. & Woman & 63 & 55,33 \\
\hline \multicolumn{4}{|c|}{ Tingkat Pendidikan } \\
\hline 1. & Elementary School & 8 & 7,33 \\
\hline 2. & Junior High School & 10 & 8,67 \\
\hline 3. & Senior High School & 73 & 64,00 \\
\hline 4. & DIPLOMA & 7 & 6,00 \\
\hline 5. & Bachelor /S1 & 15 & 13,33 \\
\hline 6. & Post graduate/S2 & 1 & 0,67 \\
\hline \multicolumn{4}{|c|}{ Family Members (person) } \\
\hline 1. & $1 \mathrm{~s} / \mathrm{d} 2$ & 33 & 29,33 \\
\hline 2. & $3 \mathrm{~s} / \mathrm{d} 4$ & 70 & 61,33 \\
\hline 3. & $5 \mathrm{~s} / \mathrm{d} \quad 6$ & 11 & 9,34 \\
\hline \multicolumn{2}{|r|}{ Amount } & 114 & 100,00 \\
\hline
\end{tabular}

Source: Primary data, Year 2021

Table 1 shows that in terms of age, 39 respondents or 34.21 percent were between 39 to 42 years old. Respondents aged 35 to 38 years were 21 respondents or 10.53 percent. While those aged 55 to 58 years, there were 5 respondents or 4.39 percent. Based on the description of the age data, it can be seen that most of the respondents (95.61 percent) are productive because the provisions of the productive age in Indonesia are 19-54 years. The productive age of the respondents is expected to provide an objective perception regarding statements regarding: knowledge of Micro and Small Business actors, level of internet use, types of internet media, digital marketing, and performance of Micro and Small Businesses.

Based on gender, as many as 83 respondents or 55.33 percent were women. Meanwhile, for men, there were 51 respondents or around 44.67 percent. The description of the gender data indicates that the perpetrators of Micro and Small Enterprises in the research location are generally women. This is because most Micro and Small Enterprises are related to the production and marketing of food and beverage (culinary) ingredients.

Based on the level of formal education, as many as 73 respondents or 64.00 percent have a high school education. Respondents with undergraduate education were 15 respondents or 13.33 percent. Meanwhile, there is 1 respondent with a Masters degree or 0.67 percent. The description of respondents' education level data indicates that the education of Micro Small Business actors is classified as secondary education so that it is expected to provide objective information regarding statements regarding: knowledge of Micro and Small Business actors, level of internet use, types of internet media, digital marketing, and performance of micro and small businesses.

Based on the family members, there are 70 respondents or 61.33 percent who have family members between 3 to 4 people. Respondents who have family members between 1 to 2 people are 33 respondents or 29.33 percent. Description of the respondent's family member data, gives an indication that Micro and Small Business actors carry out government programs, namely family planning so that the burden of dependents is small and it is hoped that their welfare will improve and are expected to improve their business performance..

\section{b. Business Characteristics}

The characteristics of Micro and Small Enterprises in this study are the length of starting the business, the number of workers, the source of labor, the origin of the business, the source of capital and the type of business or product produced. Based on the results of the study, the characteristics of Micro and Small Business actors are shown in the following table: 
Table 2. Respondents of Micro and Small Business Actors Based on Business Characteristics

\begin{tabular}{|c|c|c|c|}
\hline \multicolumn{2}{|c|}{ Time to Start a Business (Years) } & \multirow{2}{*}{$\begin{array}{c}\begin{array}{c}\text { Number of Respondents } \\
\text { (Persons) }\end{array} \\
58\end{array}$} & \multirow{2}{*}{$\begin{array}{c}\text { Persentase (\%) } \\
50,88\end{array}$} \\
\hline 1 & $3 \mathrm{~s} / \mathrm{d} 5$ & & \\
\hline 2 & $6 \mathrm{~s} / \mathrm{d} \quad 8$ & 30 & 26,32 \\
\hline 3 & 9 s/d 11 & 16 & 14,04 \\
\hline 4 & $12 \mathrm{~s} / \mathrm{d} 14$ & 4 & 3,51 \\
\hline 5 & $15 \mathrm{~s} / \mathrm{d} 17$ & 3 & 2,63 \\
\hline 6 & $18 \mathrm{~s} / \mathrm{d} 20$ & 2 & 1,75 \\
\hline 7 & $21 \mathrm{~s} / \mathrm{d} 24$ & 1 & 0,88 \\
\hline \multicolumn{4}{|c|}{ Labor (Person) } \\
\hline 1 & $1 \mathrm{~s} / \mathrm{d} 4$ & 84 & 73,33 \\
\hline 2 & $5 \mathrm{~s} / \mathrm{d} 19$ & 30 & 26,67 \\
\hline \multicolumn{4}{|c|}{ Source of Labor } \\
\hline 1 & Family (husband/wife/children) & 18 & 16,00 \\
\hline 2 & Relatives & 27 & 24,00 \\
\hline 3 & Not Family / Relatives & 69 & 60,00 \\
\hline \multicolumn{4}{|c|}{ Business Origin } \\
\hline 1 & Self-built & 109 & 95,61 \\
\hline 2 & Parent's inheritance & 3 & 2,63 \\
\hline 3 & Others (cooperation) & 2 & 1,76 \\
\hline \multicolumn{4}{|c|}{ Capital Source } \\
\hline 1 & Personal Savings & 87 & 76,32 \\
\hline 2 & Savings + Islamic Bank & 9 & 7,89 \\
\hline 3 & Savings + Conventional Bank & 14 & 12,28 \\
\hline 4 & Savings + Non-bank debt & 4 & 3,51 \\
\hline \multicolumn{2}{|c|}{ Amount } & 114 & 100,00 \\
\hline
\end{tabular}

Sumber : Data primer, Tahun 2021.

Table 2 shows that as many as 58 respondents or 50.88 percent have started a business for 3 to 5 years. Respondents who have started a business for 6 to 8 years are 30 respondents or 26.32 percent. Meanwhile, those who have started a business for 21 to 24 years have 1 respondent or 0.88 percent. The description of the old data on starting a business indicates that the Micro Small Business actors studied in general have had sufficient business experience so that it is expected to improve their business performance from both financial and non-financial aspects to ensure business continuity.

Based on the number of workers, as many as 84 respondents employed a workforce of 1 to 4 people or 73.33 percent (micro-enterprise scale). The remaining 30 respondents or 26.67 percent employ a workforce of 5 to 19 people or 26.67 percent (small business scale). Based on the source of labor, the results showed that 69 respondents or 60.00 percent used non-family/relative workers. Respondents who employ workers come from relatives as many as 27 respondents or 24.00 percent. While the respondents who employ workers come from family members as many as 18 respondents or 16.00 percent. This means that most Micro and Small Business actors prefer to employ workers who are not family/relatives because they are relatively easier to manage and expand family relationships.

Based on the origin of the business, the results of the study show that 109 respondents or 95.61 percent of the origin of the business were built by themselves. Meanwhile, the source of their business is from the inheritance of their parents, there are 3 respondents or 2.63 percent and it is a collaboration, there are 2 respondents or 1.76 percent. Respondents who use personal savings as many as 87 respondents or $76.32 \%$ and conventional banks and Islamic banks respectively as many as 14 respondents (12.28 percent) and 9 respondents ( 7.89 percent). While the respondents who use personal savings and non-bank debt are 4 respondents or 3.51 percent. This non-bank source was obtained from a business partner, PT. Pos Indonesia Kendari and share with the family.

\section{c. Descriptive Research Variables}

The variables in this study include: knowledge of Micro and Small Business actors, level of internet use, types of internet media, digital marketing, performance of Micro and Small Enterprises. The description of each variable is as follows: 
Table 3. Descriptive Recapitulation of Research Variables

\begin{tabular}{|c|l|c|c|}
\hline No & \multicolumn{1}{|c|}{ Research Variable } & $\begin{array}{c}\text { Average Perception of Micro } \\
\text { and Small Business Actors }\end{array}$ & Perception Category \\
\hline 1 & Knowledge of Micro Small Business Actors & 4,02 & Well \\
\hline 2 & Internet Usage Rate & 4,04 & Well \\
\hline 3 & Internet Media Type & 4,04 & Well \\
\hline 4 & Digital Marketing & 4,07 & Well \\
\hline 5 & Micro Small Business Performance & 4,10 & Well \\
\hline
\end{tabular}

Source: Primary Data, 2021

Table 3 shows that the knowledge of the respondents of Micro and Small Enterprises about digital marketing is relatively good when observed from the indicators of knowledge about the function of the internet, internet use and knowledge of the benefits of the internet, marked by the average perception of knowledge, which is 4.02.

Empirical facts prove that the indicator of knowledge about the function of the internet is good in its implementation which is marked by an average perception score of 4.06 which is reflected in Micro and Small Business actors, namely knowing well about the function of the internet as digital marketing, being selective in using the internet and achieving good sales. planned by utilizing digital marketing. The indicator of knowledge about internet use is good in its implementation which is marked by an average perception of 4.01 which is reflected in Micro and Small Business actors, namely knowing how to use the internet well, being selective in using the internet and using the internet specifically to support marketing activities so as to improve business performance.

The indicator of knowledge about the benefits of the internet is not yet fully optimal in its implementation which is marked by the lowest average perception of 3.99 which is reflected in Micro and Small Business actors who do not fully know the benefits of the internet, are less responsible for using the internet and have not fully enjoyed the results of using digital marketing.

The type of internet media used by respondents of Micro Small Business actors varies, namely social media (Facebook, Whatsapp, Instragram, Twitter, Line, Youtube). Also use the website and email. Its use varies depending on the tastes of Micro and Small Business actors and is already good in its use which is indicated by the average perception of the type of internet media, which is 4.04 . Empirical facts prove that social media indicators (Facebook, Whatsapp, Instragram, Twitter, Line, Youtube) are good in their use, which is indicated by the average perception score of 4.05. This means that Micro and Small Business actors have taken advantage of various existing social media to sell their products. The indicators for the use of websites and emails are also good, which is indicated by the average perception of 4.03 which is reflected in MSME actors who have used existing websites and emails to sell their products.

The use of digital marketing by Micro and Small Business actors is relatively good when viewed from the point of view of increasing the business point of view, increasing distribution, increasing the number of goods/services using consumer feedback, awareness of business image, building interaction with consumers and increasing the number of consumers, marked by the average perception about digital marketing which is 4.07. Empirical facts, proving that the purpose of digital marketing is to increase the business point of view and increase distribution, each of which is good in its implementation, which is marked by an average perception score of 4.06 which is reflected in knowing sales developments, evaluating sales results and taking actions to make improvements. in the deviation of sales results.

The indicator of increasing the number of goods and services using customer responses has been good in its implementation which is marked by the average perception of 4.04. That is, with the use of digital marketing, the sale of goods from Micro and Small Business actors has increased. Furthermore, the indicator of increasing awareness of business image is good in its implementation which is marked by an average perception score of 4.11 which is reflected in Micro Small Business actors knowing well about awareness of business image, being selective in using the internet and achieving planned sales. The indicator of building interaction with customers has been good in its implementation which is marked by an average perception score of 4.10 which is reflected in Micro Small Business actors interacting and collaborating with customers. Then the indicator of increasing the number of consumers has also been good in its implementation which is marked by an average perception score of 4.05. That is, with digital marketing, sales results will increase.

The performance of Micro and Small Enterprises from business actors is relatively good when viewed from the indicators of efficiency in selling costs, market opportunities, competitive advantages, profits, market growth which is marked by a perception average of 4.10. Empirical facts prove that the efficiency indicator of selling costs is perceived as good in its implementation, which is indicated by the perception average score of 4.10 which is reflected in the decreasing costs incurred in selling activities. Furthermore, the market opportunity indicator was perceived well by respondents with an average score of 4.08 which was reflected in the increasing share of the market controlled by Micro and Small Business actors.

The indicator of competitive advantage is perceived well by the respondents with an average score of 4.14. 
This means that Micro and Small Business actors increasingly have a competitive advantage in sales activities. The increase in profit indicator is well perceived by the respondents with an average score of 4.09. This means that the profits obtained from the business of selling products are increasing from time to time. Then, the market growth indicator has been good in its implementation which is marked by a perception average score of 4.07. That is, the increase in market area is getting bigger so that sales turnover and the number of consumers/customers are increasing.

\section{d. Data Analysis Results}

Based on research data on the knowledge of micro and small business actors, the level of internet use, internet media types, digital marketing, performance of micro and small businesses, an analysis was carried out using the SmartPLS Version 3.3.3 program to obtain the outer loading values, path coefficients and R-square as following:

Outer Loadings

\begin{tabular}{|c|c|c|c|c|c|c|c|}
\hline \multirow[t]{2}{*}{ 囯 Mean, STDEV, T-Values, P-Values } & \multirow[t]{2}{*}{ 䀡 } & Confidence Intervals & \multicolumn{2}{|c|}{ Confidence Intervals Bias Corrected } & \multirow{2}{*}{\begin{tabular}{|l} 
Samples \\
T Statistics (|O
\end{tabular}} & \multicolumn{2}{|c|}{ Copy to Clipboard: } \\
\hline & & Original Sample $(O)$ & Sample Mean (... & Standard Deviatio... & & /STDE... & P Values \\
\hline X11 <- PENGETAHUAN & & 0.895 & 0.889 & 0.035 & & 25.771 & 0.000 \\
\hline $\mathrm{X} 12<-$ PENGETAHUAN & & 0.950 & 0.948 & 0.015 & & 64.579 & 0.000 \\
\hline X13 <- PENGETAHUAN & & 0.912 & 0.910 & 0.024 & & 38.431 & 0.000 \\
\hline X21 <- TINGKAT PENGGUNAAN_INTEF & RNET & 0.910 & 0.906 & 0.023 & & 39.041 & 0.000 \\
\hline Y15 <- DIGITAL_MARKETING & & 0.959 & 0.956 & 0.015 & & 62.555 & 0.000 \\
\hline Y16 <- DIGITAL_MARKETING & & 0.979 & 0.978 & 0.008 & & 116.489 & 0.000 \\
\hline Y21 <- KINERA_UMKM & & 0.971 & 0.970 & 0.009 & & 106.928 & 0.000 \\
\hline Y $22<-$ KINERJA_UMKM & & 0.969 & 0.966 & 0.011 & & 87.232 & 0.000 \\
\hline Y $23<-$ KINERJA_UMKM & & 0.969 & 0.967 & 0.010 & & 93.933 & 0.000 \\
\hline Y24<- KINERJA_UMKM & & 0.967 & 0.965 & 0.013 & & 75.906 & 0.000 \\
\hline Y $25<-$ KINERIA_UMKM & & 0.972 & 0.970 & 0.010 & & 99.167 & 0.000 \\
\hline
\end{tabular}

Based on the output of outerloading, it is revealed that the knowledge variable of Micro and Small Business actors is significantly shaped by knowledge of the function of the internet as a product communication tool, knowledge of using the internet for new market expansion and knowledge of the benefits of the internet to target consumers. Of the 3 indicators, the most dominant is knowledge about the use of the internet for new market expansion, which is marked by the highest outerloading value, which is 0.950 and the lowest is knowledge about the function of the internet as a product communication tool, which is 0.895 .

The variable level of internet use by Micro and Small Business actors is significantly shaped by the frequency of being online on the internet and monitoring sales, marketing, and others through the internet. Of the 2 indicators, the most dominant is monitoring sales, marketing, and others, which are marked by the highest outerloading value, which is 0.915 and the lowest is the online frequency on the internet, which is 0.910 ..

The variable type of internet media by Micro and Small Business actors is significantly shaped by social media (Facebook, Whatsapp, Instragram, Twitter, Line, Youtube) and Website, Email. Of the 2 indicators, the most dominant is social media which is marked by the highest outerloading value of 0.989 and the lowest is Website, Email which is 0.988 .

Digital marketing variables are significantly shaped by increasing business perspective, increasing distribution, increasing goods and services using customer feedback, awareness of business image, building interaction with customers, increasing number of consumers. Of the 6 indicators, the most dominant is an increase in the business point of view, which is marked by the highest outerloading value, which is 0.991 and the lowest is awareness of business image, which is 0.966 .

Micro and small business performance variables are significantly shaped by cost efficiency of sales, new market opportunities, increased competitive advantage, increased profits and increased market growth. Of the 5 indicators, the most dominant is the increase in market growth which is indicated by the highest outerloading value of 0.972 and the lowest is an increase in market growth of 0.967. . 


\section{Path Coefficients}

\begin{tabular}{|c|c|c|c|c|c|c|c|c|}
\hline \multirow[t]{2}{*}{ Mean, STDEV, T-Values, P-Values } & \multirow[t]{2}{*}{ Confidence Intervals } & \multicolumn{2}{|c|}{ 囯 Confidence Intervals Bias Corrected } & \multirow{2}{*}{$\begin{array}{l}\text { Samples } \\
\text { Standard Devia }\end{array}$} & \multicolumn{2}{|c|}{ Copy to Clipboard: } & \multirow{2}{*}{$\begin{array}{l}\text { Excel Format } \\
\text { tics (|O/STDEV) }\end{array}$} & \multirow{2}{*}{$\begin{array}{l}\text { R Format } \\
\text { P Values }\end{array}$} \\
\hline & & Original Sample (0) & Sample Mean (M) & & tion (STDEV) & T Stati & & \\
\hline \multicolumn{2}{|c|}{ DIGITAL_MARKETING $>$ KINERJA_UMKM } & 0.980 & 0.978 & & 0.007 & & 148.370 & 0.000 \\
\hline \multicolumn{2}{|c|}{ TINGKAT PENGGUNAAN_INTERNET -> DIGITAL_MARKETING } & 0.366 & 0.372 & & 0.079 & & 4.655 & 0.000 \\
\hline \multicolumn{2}{|c|}{ TIPE MEDIA_INTERNET -> DIGITAL_MARKETING } & 0.355 & 0.349 & & 0.101 & & 3.502 & 0.001 \\
\hline \multicolumn{2}{|l|}{ PENGETAHUAN $->$ DIGITAL_MARKETING } & 0.277 & 0.278 & & 0.091 & & 3.034 & 0.003 \\
\hline
\end{tabular}

Based on path coefficients, digital marketing has a positive $(0.980)$ and significant $(0.000<0.05)$ effect on the performance of micro and small businesses. That is, with the good implementation of digital marketing which is implemented in increasing the business point of view, increasing distribution, increasing goods and services using customer feedback, awareness of business image, building interaction with customers, increasing the number of consumers can improve the performance of micro and small businesses which is reflected in the efficiency of selling costs, new market opportunities, increased competitive advantage, increased profits and increased market growth.

The level of internet use has a positive $(0.366)$ and significant $(0.000<0.05)$ effect on digital marketing. That is, a well-implemented level of internet usage on online frequency on the internet and monitoring sales, marketing, and others via the internet can improve digital marketing which is reflected in an increase in business perspective, increased distribution, increased goods and services using customer feedback, awareness of business image, build interaction with customers, the number of consumers increases.

The type of internet media has a positive $(0.355)$ and significant $(0.001<0.05)$ effect on digital marketing. That is, with the good type of internet media that is implemented on the use of social media (Facebook, Whatsapp, Instagram, Twitter, Line, Youtube) and Website, Email can improve the use of digital marketing which is reflected in increasing the business point of view, increasing distribution, increasing goods and services using customer feedback, awareness of business image, build interaction with customers, the number of consumers increases.

Knowledge has a positive $(0.277)$ and significant $(0.003<0.05)$ effect on digital marketing. That is, with good knowledge of the function of the internet as a product communication tool, knowledge of the use of the internet for new market expansion and knowledge of the benefits of the internet to target consumers can improve the use of digital marketing which is reflected in increasing business perspectives, increasing distribution, increasing goods and services using feedback. customers, awareness of business image, build interaction with customers, the number of consumers increases..

\section{R Square}

\begin{tabular}{|c|c|c|c|c|}
\hline \multirow[t]{2}{*}{ Matrix } & 䟩前 R Square & \multicolumn{2}{|c|}{ R Square Adjusted } & \\
\hline & & R Square & \multicolumn{2}{|c|}{ R Square Adjusted } \\
\hline \multicolumn{2}{|c|}{ DIGITAL_MARKETING } & 0.965 & & 0.963 \\
\hline \multicolumn{2}{|c|}{ KINERJA_UMKM } & 0.960 & & 0.959 \\
\hline
\end{tabular}

Based on R-Square, Knowledge Variable, Internet Usage Level and Internet Media Type contributed 96.3\% to digital marketing. Furthermore, digital marketing has contributed to the performance of micro and small businesses in Kendari City by $95.9 \%$.

The results of the analysis using the help of the SmartPLS Version 3.3.3 application obtained a model for improving the performance of micro and small businesses using digital marketing as follows: 


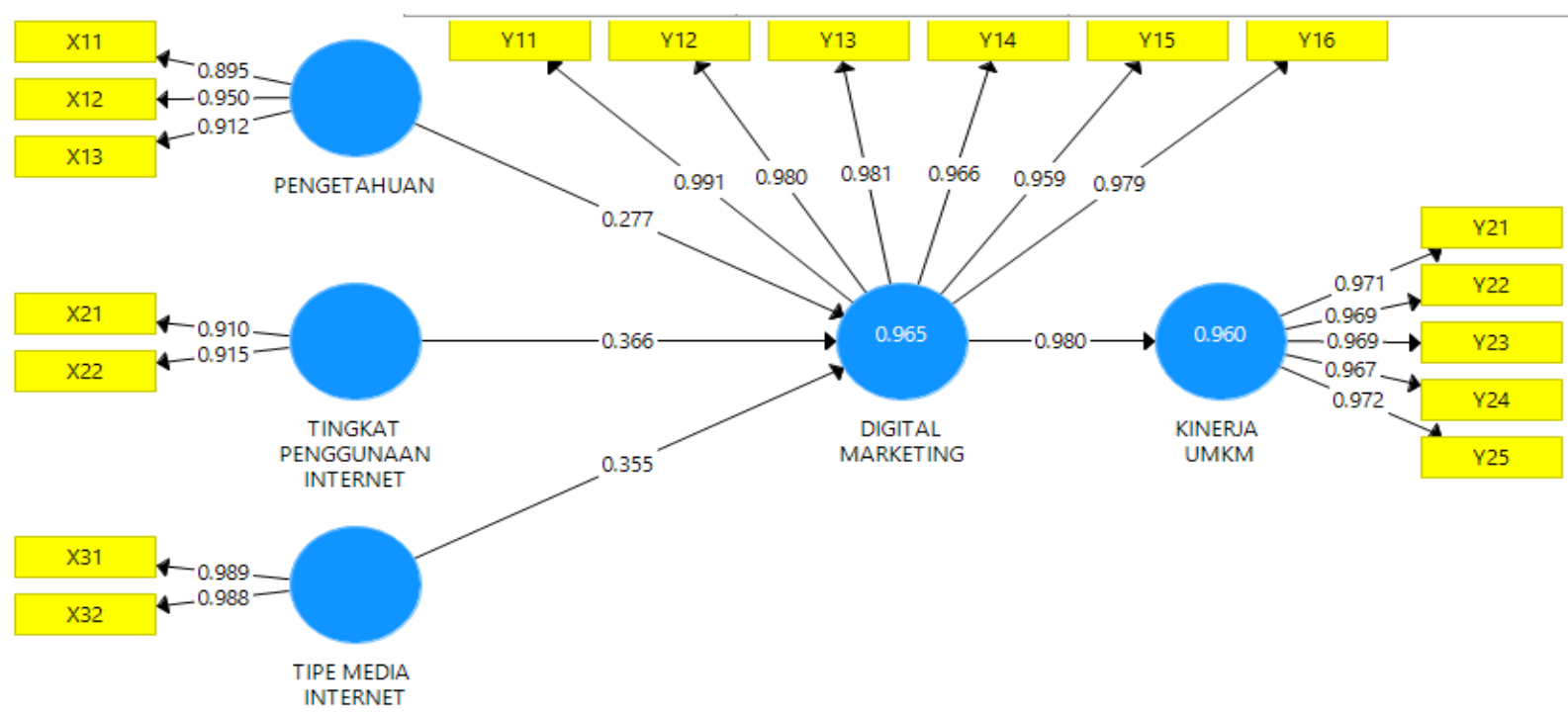

Gambar 1. Model Meningkakan Kinerja Usaha Mikro Kecil Menggunakan Digital Marketing.

Based on this model, it was revealed that to improve the performance of micro and small businesses, digital marketing should be implemented, namely implementing an increase in business perspective, increasing distribution, increasing goods and services using customer feedback, awareness of business image, building interaction with customers and increasing the number of consumers. However, it is necessary to increase digital marketing knowledge for Micro and Small Business actors, paying attention to the level of internet use and the type of internet media used, especially social media, in addition to websites and email.

\section{DISCUSSION}

Based on the results of the study, it was revealed that to improve the performance of micro and small businesses, it can be done by implementing digital marketing, namely implementing an increase in business perspective, increasing distribution, increasing goods and services using customer feedback, awareness of business image, building interaction with customers and increasing the number of consumers.

To streamline the application of digital marketing, Micro and Small Business actors need to increase digital marketing knowledge for micro and small business actors, paying attention to the level of internet use and the type of internet media used, especially social media, in addition to websites and email. In order to increase the knowledge of micro and small business actors related to digital marketing, what needs to be done is to increase knowledge about the function of the internet as a product communication tool, knowledge about using the internet for new market expansion and knowledge about the benefits of the internet to target consumers. The trick is to provide training as well as socialization by PT Telkomsel which is facilitated by the Department of Cooperatives and SMEs of Southeast Sulawesi Province.

In the context of the use of digital marketing in relation to the level of internet use by Micro and Small Business actors, the most important thing to note is the frequency of being online on the internet and monitoring the development of product sales, and customers. Furthermore, related to the type of internet media by Micro and Small Business actors in the context of digital marketing, what is important to note is the use of social media (Facebook, Whatsapp, Instragram, Twitter, Line, Youtube) and Website, Email.

The results of this study, strengthen the theory put forward by: Mohd Irwan (2014) lack of understanding of technology will have a negative impact on small businesses. Icha (2016) effective social media marketing is even new to the marketing world and more effective when compared to traditional forms of marketing. Khan and Siddiqui in their journal quoted from Purwana (2017), digital marketing comes from the internet. According to Ridwan Sanjaya and Josua Tarigan (2009), digital marketing is a marketing activity including branding that uses various web-based media such as blogs, websites, e-mail, Adwords, or social networks. Dave Chaffey (2015), digital marketing or digital marketing has almost the same meaning as electronic marketing, both of which describe the management and implementation of marketing using electronic media. The use of the internet by SMEs facilitates instant exchange of information, stimulates efficiency and helps solve problems (Carniels, 2014). The use of social media is considered to have a positive impact on a business, in particular it can reduce large marketing costs and improve good relationships with customers (Mokhtar 2016). The use of digital marketing gives hope for SMEs to develop into centers of economic power (Purwana, 2017).

The six main channels of digital media channels according to Chaffey and Smith (2015) are: a.) Search Engine Marketing (SEM), b.) Online PR, c.) Online partnerships, d.) Interactive advertising. e.) Opt-in email marketing. f.) Social media marketing. Stelzner quoted from Purwana (2017), social media has the potential to help SMEs in 
marketing their products. Stockdale, Ahmed, and Scheepers succeeded in identifying the business value of using social media for SMEs, as quoted by Purwana (2017), namely as follows: a) The creation of sustainable marketing channels; b) Increase in short-term revenue and long-term sales; c) Reducing advertising costs by up to 70\%; c) Reduction in overall marketing costs; d) Creation of competitive advantage; e) Ease of promotion across social media platforms; f) Increasing the popularity of brands and products; g) Introduction of the company to the public.

Setiowati (2015) the application of ICT by SMEs in Indonesia is still very slow. According to research by Demishkevich (2015), it is important to know the level of adoption of internet marketing among small businesses. The most common barriers are lack of knowledge about the benefits of Computer Information Technology, concerns about security and privacy, lack of skilled workers, cultural barriers, and lack of financial resources (Khatibi, 2003). Saptadi (2014) stated, in order to improve the competitiveness of SMEs, the Indonesian government facilitates e-business training for SMEs. Pawar (2014) explains that current customers tend to use social media more, the use of websites is now a place to provide information about products to potential buyers.

Kaplan and Haenlein (2010) social media is a group of internet-based applications and is built on the ideological and technological framework of the Web 2.0 platform. Ad users can create their own content that is interesting and seen by many people. Slyvia (2013) describes five main characteristics in social media: a) Participation, Openness c.) Conversation. d) Community, social media offers a mechanism for individuals or organizations to form communities that share common interests. e) Connectedness.

Zarella (2005) says the role of social media in marketing includes: a) Social media can provide identity about the products offered. b.) Serving as marketing research in an effort to find information about consumer needs. c) Social media can be used as a communication link between marketers and consumers, d) Social media brings companies closer to consumers. e) Social media is intended to build the quality of interaction (customer engagement). According to Chaffey (2015), there are 6 (six) categories of social media: a) Social networking. b) Social knowledge. c) Social sharing d) Social news. e) Social streaming. f) Company user-generated content and community.

Muttaqin (2011) Facebook Marketing is conducting marketing activities using all the facilities provided by Facebook with the aim of increasing sales and establishing closer communication with customers. Nisrina (2015), Instagram is an application that is used to share photos and videos. According to Atmoko (2012), as an application that is in demand by many users, Instagram is a social media that has lots of opportunities for business for its users, which can be used as a marketing communication medium. According to Atmoko (2012) indicators of a social media are: a)Hashtags. b) Location (Geotag). c) Follow. d) Share. e) Likes. Love symbol, f) Comment or comments. g) Mention.

The results of this study, strengthen the results of research proposed by: Lorraine Wahu Kithinji (2014), found that the use of internet marketing has a positive impact on business performance. Rini Setiowati (2015), found that a valuable insight that can educate SME managers about the potential benefits they will get is internet adoption. Ridwan (2019) found that Digital Marketing was able to create increased marketing in SMEs. Jenyo Gabriel and Soyoye Kolapo (2015) found that today's businesses are spending more and taking part in online marketing than ever before. Mayank Kumar (2018) found that digital channels influence customer opinions because of the ease of communication between customers. Arifuddin (2019) found Digital Marketing to have a positive and significant influence on Purchase Decisions. Ugonna (2017) found that appropriate marketing communication channels have a significant influence on the regularity of visits. Furthermore, Tiffany (2018) finds that digital channels in the near future influence customer buying opinions. Then Samsona's (2014) research found that online digital media has a positive influence on potential customers' purchasing decisions

Based on the description of the discussion, it can be seen that to improve the performance of micro and small businesses can be done by implementing digital marketing, namely implementing an increase in business perspective, increasing distribution, increasing goods and services using customer feedback, awareness of business image, building interaction with customers and increasing the number of consumers. . To make the application of digital marketing effective, Micro and Small Business actors need to increase their knowledge of digital marketing, increase the level of internet use and use various types of social media.

\section{CONCLUSION}

Based on the results of research and discussion, it is concluded that to improve the performance of micro and small businesses can be done by implementing digital marketing, namely implementing an increase in business perspective, increasing distribution, increasing goods and services using customer feedback, awareness of business image, building interaction with customers and increasing the number of consumers. . To streamline the application of digital marketing, Micro and Small Business actors need to increase their knowledge of digital marketing, increase the level of internet use and use various types of social media.

\section{LIMITATIONS AND SUGGESTIONS FOR FURTHER RESEARCHERS}

This research has limitations on the range of material physical aspects in improving the performance of Micro and 
Small Enterprises, namely by applying digital marketing. Therefore, there is another side that has not been implemented, namely the mentality/religious spirituality side. This is what is often called religiosity. The best concept in improving the performance of Micro and Small Enterprises is to carry out physical and material efforts simultaneously with spirituality. If this is done, there will be a very big leap in the achievement of improvements as well as improving the performance of Micro and Small Enterprises. Based on these conclusions, the following are suggested:

a. The need to increase the knowledge of Micro and Small Business actors about digital marketing by providing training as well as socialization by PT Telkomsel in the facilitation of the Cooperatives and SMEs Office of Southeast Sulawesi Province.

b. The need to increase the online frequency of Micro and Small Business actors so that they can closely monitor sales developments and the number of customers.

c. The need to think about preparing a master website for all Micro and Small Business actors coordinated by the Department of Industry and Trade to make it easier to market their products.

d. For other researchers, it is better to develop this research in the scope of application of religious values so that there is a combination of physical and material efforts with religious spirituality in improving or increasing the performance of Micro and Small Enterprises.

\section{REFERENCE}

1. Arief Rahmana, "Usaha Kecil dan Menengah (UKM), Informasi Terdepan tentang Usaha Kecil Menengah" dalam http://infoukm.wordpress.com diakses pada 15 Februari 2018 pukul21.40 WIB

2. Ascharisa Mettasatya Afrilia (2018), Digital Marketing Sebagai Strategi Komunikasi Pemasaran "Waroenk Ora Umum” Dalam Meningkatkan Jumlah Konsumen. Volume 1 Nomor 1 Februari 2018: 147-157, P-ISSN: 2615-0875 E-ISSN: 2615-0948

3. Atmoko, Bambang Dwi, 2012. Instagram Handbook. Jakarta: Media Kita

4. Bank Indonesia, "Undang-Undang No. 20 tahun 2008” dalam http://bi.go.id/uu-bi-/documents diakses pada 15 Februari 2018 pukul 13.00 WIB

5. Agus Hermawan (2015). Komunikasi Pemasaran. (Jakarta: Penerbit Erlangga), hlm. 48

6. Asosiasi Penyelenggara Jasa Internet Indonesia, "Infografis Penetrasi \& Perilaku Pengguna Internet Indonesia Survey 2017" dalam http://apjii.or.id/survei 2017, diakses pada 08 Januari 2018, pukul 22.00 WIB

7. Biro Humas Kementrian Komunikasi dan Informatika, "GO DIGITAL! Gerakan Nasional UMKM Go Online”, dalam http://kominfo.go.id/, diakses pada 07 Januari pukul $22.00 \mathrm{WIB}$

8. Chafey, Dave et al. Internet Marketing: Strategy, Implementation, and Practic. (England: Pearson Education Limited,2000)

9. Cindy Rizal Putri Paramitha. Analisis Faktor Pengaruh Promosi Berbasis Sosial Media terhadap Kinerja UMK Palanggan dalam Bidang Kuliner. Thesis. Semarang: Fakulltas Ekonomi UNDIP

10. Dan Zarella. The Social Media Marketing Book. (Canada: O'Reilly Media, 2010), hlm.2-3 Dahnil MI, Kamarul MM, Juliana L, Noor FF. 2014. Factors Influencing SMEs Adoption of Social Media Marketing. Procedia - Social and Behavioural Sciences. (148) : 119 - 126.

11. Dedi Purwana ES, dkk, "Pemanfaatan Digital Marketing Bagi Usaha Mikro, Kecil, dan Menengah (UMKM) di Kelurahan Malaka Sari, Duren Sawit”. Jurnal Pemberdayaan Masyarakat Madani . Vol. 1 No. 1, Juli 2017, hlm. 2

12. Daniel Iman K dkk (2005), "Pengaruh Pemasaran Melalui Media Sosial terhadap Kesadaran Konsumen pada Produk Internasional", Jurnal Administrasi Bisnis Universitas Brawijaya Malang, Vol.24 No. 1 Juli 2005 , hlm.4

13. Dave Chaffey (2015). Digital Business and E-Commerce Management, Strategy, Implementation, and Practice..., hlm. 7-8

14. Digital Marketer, "Jasa Iklan Instagram”, dalam http://www.digitalmarketer.co.id/iklan- online/jasa-iklaninstagram/, diakses 01 Juli 2018 pada 11.15 WIB

15. Dedi Purwana ES, dkk, "Pemanfaatan Digital Marketing Bagi Usaha Mikro, Kecil, dan Menengah (UMKM) di Kelurahan Malaka Sari, Duren Sawit”. Jurnal Pemberdayaan Masyarakat Madani . Vol. 1 No. 1, Juli 2017

16. E. Kristi Poerwandari. Pendekatan Kualitatif untuk Perilaku Manusia, (Jakarta: Mugi Eka Lestari, 2005), hlm. 101

17. Fandy Tjiptono. Strategi Pemasaran Edisi III. (Yogyakarta: Penerbit Andi, 2008), hlm.3 Facebook Business, "Iklan Facebook", dalam https://business.facebook.com/business/products/ads, diakses pada 01 Juli 2018 pukul 21.00 WIB

18. Girshwyn Reddy (2016), Digital Marketing Impact on the Consumer Decision Makng Process in NIke's Customer Retail Operatins in South Africa, Gordon Institute Of Bussines Science Univity of Pretoria. Instagram Business, “Advertising”, dalam https://business.instagram.com/advertising?locale=id_ID, diakses 01 Juli 2018 pada 11.15 WIB 
19. Iwan Muhammad, Ridwan, Abdurrahman Fauzy, Isah Aisyah, Susilawati, Iwan Sofyan (2019), Penerapan Digital Marketing Sebagai Peningkatan Pemasaran Pada UKM Warung Angkringan "WAGE" Bandung, Jurnal Pengabdian Kepada Masyarakat Vol. 2 No. 1 Februari 2019, Hal. 137-142 E-ISSN : 2614-6711 137

20. Icha O. 2016. Effectiveness of Social Media Networks as a Strategic Tool for Organizational Marketing Management. J of Inter Bank and Comm.21(S2).

21. Ivanauskiene N, Vilte A, Lineta R, Vida S. 2015. The Relationship Among E-Marketing Strategy and Success of Internationalization Process of The SMEs in Emerging Economies. EJBR. 10(2).

22. Jenyo Gabriel K and Soyoye Kolapo M (205), Online Marketing And Consumer Purchase Behaviour: A Study Of Nigerian Firms.

23. K.R. Mahalaxmi dan P. Ranjith, A Study on Impact of Digital Marketing in Customer Purchase Decision in Trichy, International Journal for Innovative Research in Science \& Technology, Volume 2, Issue 10, March 2016 ISSN (online): 2349-6010.

24. Khatibi A, Thyagarajan V, Seetharaman A. 2003. E-commerce in Malaysia: Perceived Benefits and Barriers. VIKALPA. 28(3): 77-82.

25. Kotler.P\& Keller.K.L 2007. "Manajemen Pemasaran”, Edisi ke 12, Jilid

26. Kotler, Philip. 2007. "Manajemen Pemasaran”, edisi ke 12, Jilid 1, Jakarta:PT. Indeks Kelompok Gramedia

27. Kotler, Philip \& Amstrong.2008. Prinsip-Prinsip Pemasaran.Edisi 12.Jilid 1. Alih Bahasa : Bob Sabran.Jakarta:Erlangga

28. Lorraine KW. 2014. Internet marketing and Performance of Small and medium Enterprises in Nairobi County [disertasi]. Nairobi (KE): University of Nairobi.

29. Lexy J. Moeleong. Metodologi Penelitian Kualitatif Edisi Revisi (Bandung: PT. Remaja Rosdakarya, 2007), hlm.6

30. Lexy J. Moleong, Metodologi Penelitian Kualitatif (Bandung: Remaja Rosdakarya, 2009), hlm.137

31. Mayank Kumar Rai (2018), A Study of Efficacy of Digital Marketing on Consumer Purchase Behavior in Allahabad District, International Journal for Research in Applied Science dan Engineering Technology (IJRASET) ISSN: 2321-9653; IC Value: 45.98; SJ Impact Factor: 6.887 Volume 6 Issue II.

32. Morissan. Periklanan: Komunikasi Pemasaran Terpadu. (Jakarta: Kencana Prenada Media, 2015), hlm.8

33. Mokhtar NF. 2015. digital marketing Adoption by Small Business Enterprises in Malaysia. International Journal of Business and Social Science. 6(1).

34. Nely Mariana, "10 UKM Indonesia yang Sudah Tembus Pasar Global” dalam http://goukm.id, diakses pada 07 Januari 2018, pukul 21.34 WIB

35. Nisrina M, Bisnis Online, Manfaat Sosial Media Dalam Meraup Uang, (Yogyakarta: Kobis, 2015), hlm.137

36. Naseeth Ahamed Nizar and Chrishankar Janathanan (2018), Impact of digital marketing on consumer purchase behaviour, APIIT Business, Law \& Technology Conference, 2018, July 19.

37. Pawar AV. 2014. Study of the Effectiveness of Online Marketing on Integrated Marketing Communication. NaviMumbai [disertasi]. Navi Mumbai (IN): DY Patil University.

38. Peter Salim dan Yenny Salim, Kamus Bahasa Indonesia Kontemporer, Modern English Perss, Jakarta, 2002), hlm. 1598

39. Philip Kotler. Manajemen Pemasaran Jilid 1: Analisis Perencanaan, Implementasi, dan Kontrol. (Jakarta: Prenhallindo, 1997), hlm.138

40. Philip Kotler dan Gary Amstrong (2007). Dasar-dasar Pemasaran Jilid 2. (Jakarta: Indeks, 2007)

41. Rafi Mohammed. Internet Marketing: Building Advantage in a Networked Economy. (USA: McGraw-Hill, 2003)

42. Rani Rifani Arifuddin, Abdul Rahman Kadir, Nuraeni Kadir (2019), The Impact Of Personal Selling And Digital Marketing On Purchase Decision Of Insurance Policy At Pt Qbe General Insurance Indonesia, Makassar Branch . Hasanuddin Journal of Applied Business and Entrepreneurship, HJABE Vol. 2 No. 3 Juli 2019

43. R. Tiffany, S. Santhana Kamala, M. Phorkodi, (2018) A Study on Impact of Digital Marketing in Customer Purchase Decision in Thoothukudi, International Journal of Science, Engineering and Management (IJSEM) Vol 3, Issue 4.

44. Rosady Ruslan. Metode Penelitian Public Relation dan Komunikasi, (Jakarta: Raja Grafindo), hlm. 212-213

45. Rohan Samsona, Mita Mehtab, Arti Chandanic, (2014) Impact of Online Digital Communication on Customer Buying Decision. Symbiosis Institute of Management Studies Annual Research Conference (SIMSARC13). Procedia Economics and Finance 11 ( 2014 ) 872880.

46. Saptadi S, Iman S, TMA Ari S, Rajesri G. 2014. E-Business Initiatives in Indonesian Manufacturing SMEs. Jurnal Teknik Industri. 16(2):139-148.

47. Simon Kemp, "Digital in Southeast Asia in 2017” dalam http://wearesocial.com/special- reports/digitalsoutheast-asia-2017 diakses pada 08 Januari 2018 pukul 23.34 WIB

48. Strauss, A.L., and Corbin J. Basics of Qualitative Research: Grounded Theory Procedure and Technique, $2^{\text {nd }}$ 
edition. (Newburry Park, CA: Sage Publications, 1998), hlm. 42

49. Sudarwan Danim. Menjadi Peneliti Kualitatif. (Bandung: Pustaka Setia, 2002), hlm. 122-123 Sugiyono. Metode Penelitian Kuantitatif, Kualitatif dan R \& D. (Bandung: Alfabeta, 2011),hlm.430-438

50. Schiffman, Leon G. and Leslie Lazar Kanuk. 2004. Customer Behavior. Prentice Hall Inc, USA. Swastha,Basu. 1996. Asas-asas Marketing.Yogyakarta: Liberty

51. Sanjaya, Ridwan dan Josua Tarigan. 2009. Creative Digital Marketing. Jakarta: PT.Elex Media Komputindo

52. Slyvia M Chan-Olmsted., Monhee Cho, and Sangwon Lee. 2013. User Perception of Social Media: A Comparative study of Perceived Characteristics and User Profiles by Social Media. Online Journal of Communication and Media Technologies. Vol. 3, No. 4, hlm.149-178

53. Tri Nugroho Adi, "Metode Penelitian Kualitatif Selayang Pandang” dalam http://sinaukomunikasi.wordpress.com diakses pada 25 Oktober 2017 pukul $10.00 \mathrm{WIB}$

54. Ugonna, Ikechukwu, Okolo, Victor, Nebo, Gerald, Ojieze Jef (2017), Effects of Online Marketing on the Behaviour of Consumers in Selected Online Companies in Owerri, Imo State - Nigeria. International Journal of Business and Management Invention ISSN (Online): 2319 - 8028, ISSN (Print): 2319 - 801X www.ijbmi.org, Volume 6 Issue 6,June. 2017 ,PP-32-43.

55. WhatsApp, "Aplikasi Bisnis WhatsApp", dalam https://www.whatsapp.com/business?ref=fbb_ens, diakses pada 01 Juli 2018 pukul 22.00 WIB

56. Y. Maulana, "UKM Harus Manfaatkan Perkembangan Digital”, dalam http://swa.co.id/swa/csrcorner/yuswohady-ukm-harus-manfaatkan-perkembangan-digital diakses pada 07 Januari 2018 pukul 22.00 WIB

57. Zainal Muttaqin, “Facebook Marketing Sebagai Komunikasi Pemasaran Modern”, Jurnal Sistem Informasi, Vol. 1 No. 2, Juli 2011

58. Hiebing RB and Scott WC. 2003. The Successful Marketing Plan: A Disciplined and Comprehensive Approach, 3th edition. New York (US): McGraw Hill. 